\title{
HTML-Based Website Learning Training (Hypertext Markup Languange)
}

\author{
Rahmatika' ${ }^{1}$, Ulfa Pauziah², Hardian Mursito ${ }^{3}$ \\ Tehnik Informatika, Universitas Indraprasta PGRI \\ Email : pelangi_ulfa@yahoo.com
}

Received 16 June 2021 | Revised 29 June 2021 | Accepted 30 June 2021

\begin{abstract}
In today's era of globalization, websites are very familiar, where many people easily use the web or website. Some can make their own and some ask for it to be made or rather buy. Just use it and then we just need to use it. Our partners are neighborhood associations 05 and 06 which are located in Perumnas Depok Timur, which have young women and men who are curious about website development, and some young women and men want to continue their studies at a higher level by majoring in information and communication. In making a website, they need several stages that they have to apply because our partners are teenagers who are unfamiliar with website creation, for that we here want to make a basic training in website creation which will later be useful for them in terms of application in their environment and society. Where in this training introduced HTML (hypertext markup language). It is hoped that by studying HTML, teenagers can understand how to create a website with HTML.
\end{abstract}

Keywords: HTML, information, Learning, website

\section{INTRODUCTION}

Pincher ID is a local startup that aims to make it easier for teachers to promote training classes and make online registrations, especially in training in the field of technology. In addition, Pincher ID makes it easier for prospective participants to find interesting training. Currently Pincher ID is still in the form of a mobile-based application with features that are still limited, such as viewing training lists, selling training tickets, and others. Because Pincher ID is still in the form of a mobile application, Pincher ID can only be accessed via a smartphone or tablet device with the help of a third party (Google Playstore/App Store). The Pincher ID mobile application also cannot be indexed by search engines, making it difficult for people to find the Pincher ID application. The solution to this problem is the development of the Pincher ID application which was originally mobile-based into a website using web services in data integration. Web service technology is used as a facility that provides services (in the form of information or data) to other systems, so that they can interact with these systems through the services provided even though they have different platforms, operating systems, and programming languages. In addition, the process of loading a website also needs to be considered. The slow loading process will make users leave the website. Laravel is a development tool framework that is suitable because Laravel has little execution time so the website has a fast loading process ( Das \& Saikia, 2016). 
With the development of science and technology, as well as the development of information technology, the computer deserves to be called a tool in the development of information technology. Because information is very important to support sustainable development, so there is a reason that information is needed for companies, especially companies that are just developing. The system is a network of procedures that are interconnected, gathered together to carry out an activity or to complete a certain goal, and data that is processed into a form that is more useful and more meaningful to the recipient ( Ruhul, 2017) (Crampton, 2013).

An information system is a tool for presenting information in such a way that it is useful for the recipient. Its purpose is to provide information for decision-making on planning, initiating, organizing, controlling activities (Rahmawati et al, 2015). The development of information and communication technology has influenced the world of education, communication as an educational medium is carried out using communication media such as materials. The technology that is always developing is the website, institutions or government agencies now have their website which is used as a medium for information. A website is a collection of web pages, which are usually summarized in a domain or subdomain, which is located on the World Wide Web (WWW) on the Internet.

A web page is a document written in HTML (HyperText Markup Language) format, which is almost always accessible via HTTP, which is a protocol that conveys information from a website server to be displayed to users via a web browser. Learning the stages of making a website, takes time to learn it, the first thing to do in making a website is the HTML format (Hypertext Markup Language) where someone new to website creation must first understand the tags in HTML. As a markup language, HTML needed a way to tell web browsers what to do with text. Whether the text is written as a paragraph, a list, or as a link, the term in the HTM is a tag.

Website is a medium of information on the internet. The website can not only be used for the dissemination of information but can be used to create an online store. A website is a collection of web pages, which are usually summarized in a domain or subdomain, which is located on the World Wide Web (WWW) on the Internet. A web page is a document written in HTML (HyperText Markup Language) format, which is almost always accessible via HTTP, which is a protocol that conveys information from a website server to be displayed to users via a web browser.

All publications from these websites can form a very large information network. The pages of the website will be accessible through a URL which is usually called the Homepage. This URL organizes the pages of the site into a hierarchy, however, the hyperlinks on the page govern the readers and tell them the overall structure and how this information flows. Some websites require a subscription (input data) so that users can access part or all of the contents of the website ( Javacreativity, 2014).

PHP stands for Personal Home Page which is the standard language used in the world of websites. PHP is a programming language in the form of a script that is placed on a web server. PHP can be interpreted as a Hypertext Preprocessor. It is a language that can only run. Website Analysis and Design as a Means of Information on the server whose results can be displayed on the client. The PHP interpreter in executing PHP code on the server-side is called the server-side, in contrast to the Java virtual machine which executes programs on the client-side (Peranginangin, 2016). Thus, the title appears with HTML-based website learning training (hypertext markup language). Because the two partners of the Community 
Service Team (PKM), namely RT 05 and 06 RW 11 at the Perumnas, Depok Timur, West Java, are under one roof, the problems faced are identical.

The problems faced are also not far from the problem of using technology media as learning media. The following will describe some of the problems faced by Partners based on observations from the PKM Team: The youth organizations have not used information and communication technology in learning, cannot yet utilize learning media by utilizing information and communication technology. So that the emergence of Community Service activities with the theme "HTML-Based Website Learning Training (Hypertext Markup Language)".

\section{METHODS}

Arianto in his research developed an academic information system for STT Terpadu Nurul Fikri which currently uses a client-server (two-tier system) pattern. However, difficulties arise when it will be developed, namely the unavailability of services (webservices) capable of integrating the system with other systems, making development difficult, especially in terms of data exchange, integration and management. The research uses REST technology by designing two API models for two modules, namely the student module and the lecturer module. This module will generate data in JSON format. The API testing technique uses the black box testing technique with the Postman testing application tools. API testing is done on the prototype of the webservice application. The research method used is the Unified Process which uses the Yii Framework 2.0 framework (Arianto, Munir, \& Khotimah, 2016). Meanwhile, the research conducted by Rianto aims to simplify and expedite the data processing of pharmaceutical services at the Banyumas General Hospital. Obstacles found in the Pharmacy of the Banyumas RSU, namely for patient prescription services with debtors of Pharmacy officers who still have to do data entry in the Pharmacy Information System and Hospital Information System. Therefore, it is necessary to make improvements in the management of an information system using web services as data integration. The use of internet technology has colored the development of distributed computing systems with the emergence of the concept of web services. Webservices is a new paradigm in implementing a distributed system over the web that uses an XML technology base, with standard HTTP and SOAP protocols. Given the open standards used to support web services technology, the implementation of web services promises convenience and improvement in supporting the integration of various systems and application platforms, either through intranet or internet or extranet infrastructure. The steps taken start with planning, analyst, design, implementation, and testing and evaluation, so as to produce an object-based service analyst model design and webservices application as an integration of Pharmacy data at Banyumas General Hospital so that no replacement of the old system is needed (Riyanto, Utami, \& Amborowaty, 2013). Based on the literature review that has been described, it shows that the webservice has architectural methods in the form of REST and SOAP with data formats in the form of XML and JSON. Based on the consideration of each method based on previous research, this research uses a REST architecture with JSON data format. The difference between this research and previous research is that it uses the Laravel framework in making an API (Application Programming Interface) and frontend. In addition, the main objective and focus of this research is to develop a web-based training information system using web service technology for data integration. The expected result of this research is a training information system that makes it easier for people to access sites with light and fast performance and use webservice technology for data integration. Web Service is a software system designed to support interaction and interoperability between systems 
on a network. Web service is used as a facility that provides services (in the form of information or data) to other systems, so that they can interact with the system through the services provided. Webservice stores information data in JSON or XML format, so this data can be accessed by other systems even though they are different.

Before carrying out community service activities, the lecturer team researched several problems faced by partners. The method used is direct observation and conducting interviews. Based on the results of the research conducted, one of the problems faced by teachers was chosen, namely that teenagers found it difficult to use technology.

The solution offered to overcome these problems is to provide solutions for the implementation of Html-Based Websites (Hypertext Markup Language) in learning, especially regarding the presentation of material. The existence of this activity is expected to provide convenience for teenagers to be creative, especially regarding presentation in learning media. The procedures carried out in the implementation of this community service include:

1. Prepare materials and programs used in socialization.

2. Prepare socialization designs for youth.

3. Prepare facilities for socialization activities.

4. Evaluation and analysis of the results of socialization activities

Regarding the community service activities to be carried out, the two partners welcomed and positively appreciated the activity. Several forms of support provided by partners include:

1. To record and inform youth about community service activities.

2. Prepare a schedule including the place and time of the implementation of community service activities.

3. Assist by providing facilities and infrastructure for community service activities.

The methods that will be used in this activity are as follows:

1. Live Observation and Interview

Direct observation and interviews, namely servants who come directly to the service location to obtain data. The lecturer team immediately came to the service location to obtain data. This is done both before and during the activity. Observations and interviews are useful to determine the condition of the use of technology in learning in RT 05 and 06 RW 11 at Perumnas, Depok Timur, West Java, and determine the solutions that will be offered to overcome existing problems. Observations are very important for the success of community service activities themselves.

2. Presentation and Q\&A

The implementation of socialization activities to teachers in schools is carried out using presentations made by resource persons, accompanied by questions and answers, and teachers are allowed to practice the material presented.

\section{RESULTS AND DISCUSSION}

This study uses training class data from Pincher ID until June 2018. The structure of the application made consists of two parts, namely the client side and the webservice side. The application is built using the PHP programming language with the Laravel framework version 5.5 with a REST (Representational State Transfer) architectural approach. The Html-Based Website Learning Training Team (Hypertext Markup Language) was carried out by 3 people from Indraprasta University PGRI. The location for the training was carried out at the 
National Housing Center, Depok Timur, West Java, to be precise in the RT 05 and 06 RW 11 areas.

One of the reasons is that in this environment the youth training process carried out by the government is not optimal, some teenagers still have not had the opportunity to attend training, the training conducted by the government is not sustainable and there is still a lack of facilities, media, and infrastructure that support learning activities. At the beginning of the community service team's visit to the RT 05 and 06 neighborhoods, the team and the heads of RT 05 and 06 discussed the objectives, materials to be delivered and determined the coaching day determined by both parties. The first party, namely the youth, asked for guidance on learning through Html-Based Website Learning Training (Hypertext Markup Language). The second party, namely the community service team, provides learning guidance through HTML-Based Website Learning Training (Hypertext Markup Language) in the RT 05 and 06 RW 11 areas follow the guidance and good cooperation between the two parties.

In this section, the author discusses and describes the results of community service carried out at the Perumnas, Depok Timur, West Java, precisely in the RT 05 and 06 RW 11 areas, the partners who attended were youth groups and were the right target considering the internet was very popular and even important for millennial youth. From the previous analysis, the team found that many of the teenagers did not know about the background which is an important aspect in building a website that they visit every day. Even though as millennials, partners should know about it because a function of a website today is not only for information media but also as a medium of communication and even promotion of goods or services. Where the material we describe is as follows:

1. HTML History

2. Introduction to what tags, body, and elements are

3. HTML mainframe

In addition to the presentation of the material above, there is still more to practice material from a simple web using HTML. The results of the activities carried out by the team are as follows:

1. Teenagers become more aware of the background of a website that they often access every day.

2. Partners learn a new programming language, namely HTML (hypertext Markup Language) to create a website.

3. Partners try directly how to make a simple website with their smartphone media.

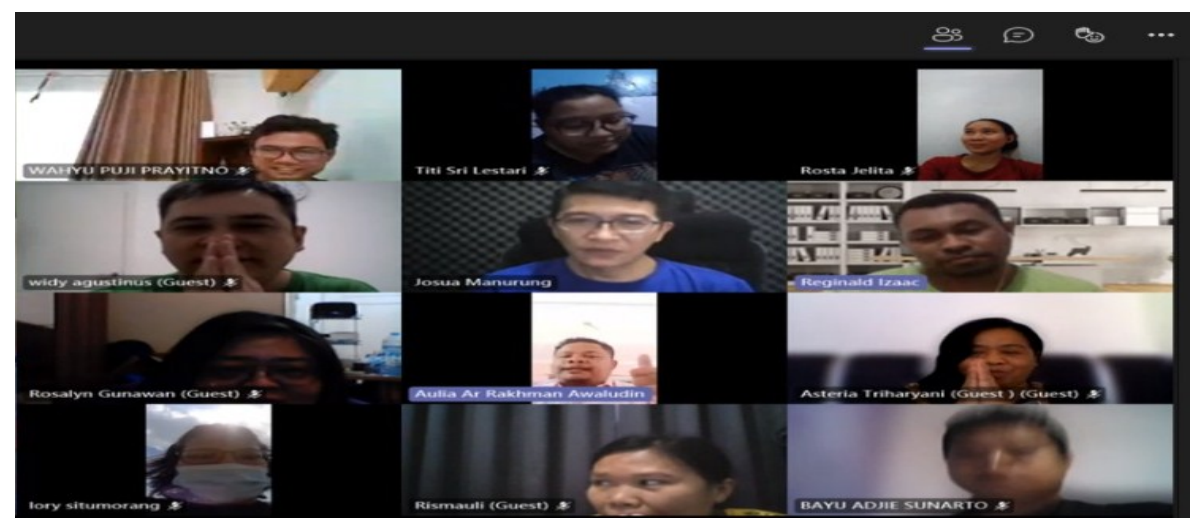

Figure 1. Implementation of Community Service Activities 
User Acceptance Testing is a test carried out by the user to test whether the application is in accordance with the wishes of the user ( Purnomo and Beeh, 2016).This test is carried out on users through interviews where at this stage an interview is conducted by RECT Academy as the user of Pincher ID. Based on the interviews conducted, it is concluded that the system that has been made is easy to use (user friendly), light and fast, and in accordance with the objectives and benefits of the research conducted. The convenience offered in this system can be seen from the initial appearance of the system which displays the latest training class posters and navigation that is easy to find and use by users. In addition, the system created can be run on all devices with various screen sizes. This system helps Pincher ID in conducting training classes.

\section{CONCLUSIONS}

Html-Based Website Learning Training (Hypertext Markup Language) which is located at Perumnas, Depok Timur, West Java, precisely in the area of RT 05 and 06 RW 11. Based on the responses, responses, and participation of the youth and the head of the RT and the management, it can be concluded that the youth felt that this coaching was very useful. Adolescents can apply the material obtained in the training according to their needs. The presence of the youth during the training in the Hall of RT 05 and 06 RW 11 was very enthusiastic. In addition, after the training was completed, the youth eagerly wanted to apply the material during the learning process because the youth wanted to be more creative and innovative in creating the learning process.

In addition, some youths from other RT areas suggested more routine training from the Community Service Team in the RT 05 and 06 RW 11 areas. today who are often referred to as millennials. The use of a website today is not only a medium of information but also a medium of communication and more importantly, can be a promotional medium for entrepreneurship, a website can also support and build trust in a consumer in the business world. To learn HTML today, besides being able to try it directly on a computer, it can also be done via a smartphone with several supporting applications, so partners can learn it anytime and anywhere.

\section{REFERENCES}

Adiwibowo, Lili., Hurriyati, Ratih., Sari, Maya., Analisis Perilaku Teknologi Informasi pada Perguruan Tinggi Berstatus BHMN, 2010.

Arianto, M. A., Munir, S., dan Khotimah, K. (2016). Analisis Dan Perancangan Representational State Transfer (Rest) Web Service Sistem Informasi Akademik Stt Terpadu Nurul Fikri Menggunakan Yii Framework. Jurnal Teknologi Terpadu, 2(2). Retrieved from http://journal.nurulfikri.ac.id/index.php/JTT/article/view/57

Crampton, P., et al. (2013). Workplace bullying in the UK NHS: a questionnaire and interview study on prevalence, impact, and barriers to reporting. BMJ Open; 3: e002628.

Das, R., dan Saikia, L. P.(2016). NComparison of Procedural PHP with Codeigniter and Laravel Frameworko Title. International Journal of Current Trends in Engineering \& Research (IJCTER), 2(6), 42-48.

JavaCreatifity. (2014). Panduan Cerdas Membangun Website Super Keren. Elek Media Komputindo. Jakarta. 
J. W. Crampton. (2013). "Mappings," Wiley-Blackwell Companion to Cult. Geogr., vol. 08, no. 50, pp. 423-436.

Jogiyanto, H.M. (2007). Sistem Informasi Keperilakuan. Yogyakarta: Andi.

M. K. Ruhul Amin. (2017). "Siswa Baru Pada Smk Budhi Warman 1 Jakarta,"ilmu pengetahuan dan teknologi komputer.,vol. 2, no. 2, pp. 113-121.

Peranginangin, Kasiman. (2006). Aplikasi WEB dengan PHP dan MySQL. Andi. Yogyakarta.

Purnomo, R., dan Beeh, Y. R. (2016). Perancangan Aplikasi Emergency Button berbasis. Android.

Rahmawati, R. Kridalukmana, and I. P. Windasari. (2015)."Pembuatan Sistem Informasi Rental Mobil dengan Menggunakan Java dan Mysql," J. Teknol. dan Sist. Komput.

Riyanto, Utami, E., dan Amborowaty, A. (2013). PEMANFAATAN WEB SERVICES PADA INTEGRASI DATA FARMASI DI RSU BANYUMAS. In Seminar Nasional Informatika 2013 (semnasIF 2013)(pp. 276-283).

Ruhul, A. (2017). Rancang Bangun Sistem Informasi Penerimaan Siswa BaruPada SMK Budhi Warman 1 Jakarta. Diambil dari: ejournal.nusamandiri.ac.id/ejurnal/index.php/jitk/article/view/282

https://www.nesabamedia.com/pengertian-tag-attribute-dan-element-di-html/

https://www.kompasiana.com/inaryati/59e7a35963eae70b7710ed02/peran-teknologiinformasi-dan-komunikasi-untuk-pendidikan-dan-pengajaran

https://www.niagahoster.co.id/blog/belajar-html/

https://www.duniailkom.com/tutorial-belajar-html-dasar-untuk-pemula

https://www.kompasiana.com/toghr9896/5b7133c843322f3056286cc2/pengertian-tentanghtml-sejarah-dan-contoh-program-html?page=telephone, computer, internet, e-mail, and so. 